\title{
Suherman, C. • I.R. Dewi • R. Wulansari \\ Pengaruh metode aplikasi dan dosis stimulan cair terhadap produksi lateks pada tanaman karet Klon PR 300 umur 25 tahun
}

Sari. Penggunaan stimulan pada tanaman karet (Hevea brasiliensis Muell. Arg.) merupakan salah satu upaya yang umum dilakukan untuk meningkatkan produksi lateks. Penggunaan stimulan bertujuan untuk memperpanjang masa aliran lateks sehingga lateks yang dihasilkan dapat lebih banyak. Penelitian ini bertujuan untuk mendapatkan kombinasi perlakuan terbaik dari metode aplikasi dan dosis stimulan cair yang digunakan untuk meningkatkan produksi lateks pada klon PR 300. Penelitian dilaksanakan pada bulan Maret sampai Mei 2015 di PT. PP Bajabang Indonesia yang memiliki ketinggian tempat 200 meter di atas permukaan laut dengan ordo tanah Inceptisol. Metode penelitian yang digunakan adalah Rancangan Acak Kelompok yang terdiri dari 11 kombinasi perlakuan yang diulang sebanyak tiga kali dengan susunan perlakuan sebagai berikut: Tanpa stimulant (A); Metode Groove + dosis 0,5 mL/pohon (B); Metode Groove + dosis 0,6 mL/pohon (C); Metode Groove + dosis 0,7 mL/pohon (D); Metode Groove + dosis 0,8 mL/pohon (E); Metode Groove + dosis 0,9 mL/pohon (F); Metode Bark + dosis 0,5 mL/pohon (G); Metode Bark + dosis 0,6 mL/pohon $(\mathrm{H})$; Metode Bark + dosis 0,7 mL/pohon (I); Metode Bark + dosis 0,8 mL/pohon (J); dan Metode Bark + dosis $0,9 \mathrm{~mL} /$ pohon. Hasil penelitian menunjukkan bahwa metode aplikasi groove dan bark yang dikombinasikan dengan beberapa dosis stimulan cair pada tanaman karet umur 25 tahun menghasilkan volume lateks yang relatif sama dengan tanpa stimulan pada klon PR 300.

Kata kunci: Klon PR $300 \cdot$ Stimulan karet · Penyadapan

\section{Effect of application method and dosages of liquid stimulant on latex production of 25 years old rubber tree Clone PR 300}

\begin{abstract}
The application of stimulant on rubber tree is one of the common efforts to increase latex production. This application is supposed to extend the period of latex flow, so that can produce more latex. The aim of this research was to get the best treatment combination of application method and liquid stimulant dosage that used to increase latex production on clone PR 300. The research was conducted from March to May 2015 at PT. PP Bajabang Indonesia at 200 meters altitude. The research was arranged using Randomized Block Design (RBD), consisted of 11 treatments and 3 replications. The treatments were: Without Stimulant (A); Groove Method $+0.5 \mathrm{~mL} /$ tree dose (B); Groove Method $+0.6 \mathrm{~mL} /$ tree dose $(\mathrm{C})$; Groove Method $+0.7 \mathrm{~mL} /$ tree dose (D); Groove Method $+0.8 \mathrm{~mL} /$ tree dose (E); Groove Method $+0.9 \mathrm{~mL} /$ tree dose $(\mathrm{F})$; Bark Method $+0.5 \mathrm{~mL} /$ tree dose (G); Bark Method +0.6 $\mathrm{mL} /$ tree dose $(\mathrm{H})$; Bark Method $+0.7 \mathrm{~mL} /$ tree dose $(\mathrm{I})$; Bark Method $+0.8 \mathrm{~mL} /$ tree dose $(\mathrm{J})$; and Bark Method $+0.9 \mathrm{~mL} /$ tree dose $(\mathrm{K})$. The results of this research showed that groove method and bark method that combined with variant dosage of liquid stimulant in 25 years old rubber plants produced the same latex with no stimulant on clone PR 300.
\end{abstract}

Keywords: Clone PR $300 \cdot$ Rubber stimulant · Tapping

Diterima : 19 September 2019, Disetujui : 19 Maret 2020, Dipublikasikan : 31 Maret 2020 doi: https://doi.org/10.24198/kultivasi.v19i1.23586

Suherman, C. • I.R. Dewi • R. Wulansari

Dosen Departemen Budidaya Pertanian Fakultas Pertanian Universitas Padjadjaran

Koresponsdensi: cucu.suherman@unpad.ac.id 


\section{Pendahuluan}

Indonesia merupakan salah satu produsen karet terbesar di dunia dengan lahan terluas yaitu sebesar 3,6 juta hektar, terdiri atas kebun rakyat 3,1 juta ha $(85 \%)$, perkebunan besar swasta $8 \%$ dan perkebunan besar negara 7\% (Direktorat Jenderal Perkebunan, 2017). Produksi karet Indonesia pada tahun 2014 tercatat hanya sebesar 2,4 juta ton sedangkan produksi karet Thailand mencapai 3-4 juta ton (Hidayat, 2014). Luasnya perkebunan tanaman karet Indonesia tidak diimbangi dengan produktivitas dan mutu yang dihasilkan. Peningkatan produktivitas lateks diperlukan untuk mendapatkan karet yang lebih baik sehingga dapat menambah keuntungan dan dapat menarik konsumen karet dunia.

Sebagian besar perkebunan karet di Indonesia merupakan perkebunan rakyat yang pada umumnya belum menggunakan bibit karet dari klon-klon unggul, pemeliharaannya masih sederhana, serta banyak tanaman karet yang sudah tua dan rusak (Balai Pengkajian Teknologi Pertanian, 2011). Keadaan ini jauh berbeda dibandingkan dengan kondisi industri karet di beberapa negara produsen karet lain yang sudah menggunakan klon-klon unggul yang disertai dengan pemeliharaan yang baik sehingga produktivitasnya lebih tinggi (Hidayat, 2014). Hal tersebut merupakan salah satu penyebab rendahnya produktivitas karet Indonesia yang menyebabkan tergesernya posisi Indonesia sebagai produsen utama karet dunia (Direktorat Jenderal Perkebunan, 2011).

Tanaman karet pada umumnya mampu berproduksi hingga umur 20-25 tahun, dan dalam masa produktifnya satu pohon dapat menghasilkan lateks lebih dari $500 \mathrm{~mL}$ setiap kali penyadapan, namun setelah masa produktifnya habis biasanya pohon karet sudah tidak mampu berproduksi secara maksimal lagi, bahkan dalam masa produktifnya terkadang produktivitasnya menurun pula (Syakir, 2010). Faktor yang mempengaruhi produktivitas lateks diantaranya jenis klon yang digunakan, sistem sadap yang dilakukan, kebersihan pohon, iklim, alat-alat yang digunakan dalam penggumpalan dan pengangkutan, proses pengangkutan, kualitas air dalam pengolahan, bahan-bahan kimia yang digunakan, dan komposisi lateks (Setyamidjaja, 1993). Usaha untuk mengatasi penurunan produktivitas lateks salah satunya dapat dilakukan dengan pemberian stimulan dalam penyadapan tanaman karet (Setiawan dan Andoko, 2005).

Penggunaan stimulan pada penyadapan tanaman karet bertujuan untuk merangsang produksi lateks dan memperpanjang masa aliran lateks (Siregar, 2001). Jenis stimulan yang sering digunakan di perkebunan karet Indonesia adalah stimulan cair dengan bahan aktif etefon (asam 2-kloro-etil-fosfat) yang merupakan salah satu kelompok penghasil etilen yang dapat meningkatkan lama aliran lateks sehingga produksinya dapat meningkat (Setyamidjaja, 1993). Stimulan ini umumnya diberikan pada tanaman karet yang telah memasuki masa produktif (tanaman karet menghasilkan yang sudah mencapai umur 15 tahun), karena pemberian stimulan pada tanaman muda dapat mempengaruhi pertumbuhan tanaman jika diaplikasikan tanpa menurunkan intensitas sadapan (Setiawan dan Andoko, 2005).

Aplikasi stimulan cair di Indonesia umumnya menggunakan metode groove dan metode bark, dimana pada metode groove dilakukan dengan menarik scrap yang ada pada panel sadap kemudian mengoleskan stimulan cair pada alur sadapnya, sementara metode bark dilakukan dengan mengerok tipis kulit yang akan disadap selebar 1-1,5 cm kemudian mengoleskan stimulan cair pada kulit yang akan disadapnya (Siregar, 2001). Kedua metode ini lebih umum digunakan karena penggunaannya relatif lebih aman dan lebih efektif dibandingkan dengan metode lainnya, tetapi sejauh ini perbedaan keefektifan dari kedua metode ini dalam meningkatkan produksi lateks masih belum banyak diteliti sehingga perlu diteliti lebih lanjut untuk mendapat metode aplikasi stimulan cair yang paling efektif untuk digunakan.

Dosis aplikasi stimulan menentukan respons tanaman dalam memperpanjang masa aliran lateksnya. Dosis yang umumnya digunakan adalah sekitar $1 \mathrm{~mL} /$ pohon dengan konsentrasi 2,5\% yang dapat diaplikasikan satu bulan sekali (Siregar, 2001). Penggunaan dosis yang tepat dalam aplikasi stimulan diharapkan dapat meningkatkan produksi lateks.

Jenis klon yang digunakan mempengaruhi respons tanaman terhadap penggunaan stimulan sehingga tidak semua tanaman karet dapat memberikan respons yang diharapkan terhadap aplikasi stimulan yang diberikan (Setiawan dan Andoko, 2005). Tanaman karet 
yang digunakan dalam penelitian ini adalah tanaman karet klon PR 300 yang berumur 25 tahun yang merupakan klon yang memiliki metabolisme rendah (termasuk jenis klon slow starter) yang memiliki karakteristik lebih responsif terhadap pemberian stimulan namun penetesan lateksnya tergolong lambat (Iswahyudi, 2011). Potensi produksi lateks pada masa produktif klon ini adalah sekitar $500 \mathrm{~mL}$ per pohon, akan tetapi klon ini sudah mulai tidak produktif yakni hanya mencapai produksi 100$200 \mathrm{~mL}$ per pohon sehingga perlu dilakukan pemberian stimulan untuk meningkatkan produksinya. Aplikasi stimulan cair menggunakan kombinasi metode dan dosis aplikasi yang tepat pada tanaman karet klon PR 300 diharapkan dapat meningkatkan produksi lateks.

\section{Bahan dan Metode}

Percobaan dilaksanakan di lahan perkebunan karet PT. PP Bajabang Indonesia yang terletak di Kampung Pasir Ucing-Cibungur, Desa Nanggeleng dan Desa Margaluyu, Kecamatan Cipeundeuy, Kabupaten Bandung Barat, Provinsi Jawa Barat yang berada pada ketinggian 212 meter di atas permukaan laut dengan ordo tanah Inceptisol yang memiliki tipe iklim C dengan rata-rata curah hujan sebesar 2500 $\mathrm{mm} /$ tahun. Percobaan dilaksanakan pada bulan Maret sampai Mei 2015.

Bahan yang digunakan pada percobaan ini adalah pohon karet klon PR 300 yang berumur 25 tahun yang ditanam dengan jarak $7 \times 3$ meter dengan sistem sadap $1 / 2 \mathrm{~s} d / 3$ (frekuensi penyadapan 3 hari sekali dengan sadap setengah spiral), stimulan cair dengan merk dagang Ethrel 10PA berbahan aktif etefon, air sebagai pelarut, amoniak sebagai pencegah koagulasi, dan asam semut untuk menggumpalkan lateks.

Alat yang digunakan pada penelitian adalah label perlakuan, alat tulis untuk mencatat data, pisau sadap, mangkuk sadap, botol berukuran $300 \mathrm{~mL}$, kuas kecil, pisau (pengerok), kantong plastik berukuran $1 / 2 \mathrm{~kg}(12 \times 25 \mathrm{~cm})$, timbangan digital, dan alat-alat pengukur kadar karet kering yaitu canting, monelglass mesh 40, gelas ukur yang berukuran $250 \mathrm{~mL}$, mangkuk plastik, pengaduk, gilingan manual, kain lap, dan timbangan digital.

Pengaplikasian stimulan cair dilakukan 2 hari sebelum penyadapan berdasarkan metode aplikasi stimulan cair yang digunakan. Aplikasi stimulan cair dilakukan dengan interval satu bulan sekali selama 3 bulan periode sadap. Dosis yang umum digunakan di PT. PP Bajabang Indonesia pada hampir semua jenis klon adalah $0,8 \mathrm{~mL} /$ pohon, sementara dosis anjuran dari stimulan cair yang digunakan pada penelitian adalah sebesar 0,6-0,9 mL/pohon (Hakim, 2012).

Penyadapan dilakukan pada bidang sadap bawah kulit pulihan ketiga, dengan kemiringan sudut $35^{\circ}$ menggunakan sistem penyadapan $\mathrm{s} / 2$ $\mathrm{d} / 3$ (sistem sadap 1/2 lingkaran; frekuensi penyadapan 3 hari sekali). Sebelum penyadapan dilakukan, mangkuk sadap diberi 2-3 tetes amoniak $\left(\mathrm{NH}_{3}\right)$ terlebih dahulu untuk mencegah prakoagulasi. Penyadapan dilakukan oleh penyadap pada pukul $08.00 \mathrm{WIB}$, ketika tekanan turgor masih tinggi.

Percobaan menggunakan Rancangan Acak Kelompok (RAK) yang terdiri dari 11 kombinasi perlakuan metode aplikasi dan dosis stimulan cair. Adapun susunannya sebagai berikut:

A: Tanpa stimulan;

B: Metode Groove + dosis 0,5 mL/pohon;

C: Metode Groove + dosis 0,6 mL/pohon;

D: Metode Groove + dosis 0,7 mL/pohon;

E: Metode Groove + dosis 0,8 mL/pohon;

F: Metode Groove + dosis 0,9 mL/pohon;

G: Metode Bark + dosis 0,5 mL/pohon;

$\mathrm{H}$ : Metode Bark + dosis 0,6 mL/pohon;

I: Metode Bark + dosis 0,7 mL/pohon;

$\mathrm{J}$ : Metode Bark + dosis 0,8 mL/pohon; dan

$\mathrm{K}$ : Metode Bark + dosis 0,9 mL/pohon. Setiap perlakuan diulang sebanyak 3 kali sehingga terdapat 33 satuan percobaan dimana tiap satuan percobaan terdiri dari 2 tanaman.

Uji statistik yang digunakan untuk mengetahui pengaruh perlakuan terhadap produksi lateks dianalisis melalui analisis ragam dengan uji $\mathrm{F}$ pada taraf kepercayaan $95 \%$. Apabila perbedaan rata-rata perlakuan pengaruhnya nyata, maka dilakukan uji lanjut dengan uji Jarak Berganda Duncan pada taraf kepercayaan $95 \%$.

\section{Hasil dan Pembahasan}

Pengamatan Penunjang. Lahan perkebunan karet di lokasi percobaan memiliki jenis tanah yang tergolong ordo Inceptisol dengan persentase liat sebesar $60,40 \%$, pasir $9,83 \%$, dan debu $27,77 \%$. Tanah ini tergolong tanah masam dengan $\mathrm{pH}$ 5,40, kadar C-organik rendah $(1,03$ $\%)$, N-Total rendah $(0,10 \%)$, kadar unsur $\mathrm{K}$ 
rendah $(0,15 \mathrm{me} / 100 \mathrm{~g})$, kadar Mg tinggi $(2,50$ me/100g), kadar unsur Na sedang $(0,54 \mathrm{me} /$ $100 \mathrm{~g})$, kapasitas tukar kation sedang 17,49 me/ $100 \mathrm{~g}$, dan kejenuhan basa rendah yaitu $37,11 \%$. Secara umum kondisi tersebut memenuhi syarat tumbuh tanaman karet (Syakir, 2010).

Selama percobaan berlangsung selama 3 bulan yaitu pada bulan Maret, April dan Mei 2015, memiliki total curah hujan masing-masing sebesar 419,6; 227,6; dan $56 \mathrm{~mm} /$ bulan. Temperatur rata-rata harian pada bulan Maret, April, dan Mei masing-masing sebesar 24,81; 24,47; dan $24,42{ }^{\circ} \mathrm{C}$ dengan temperatur terendah sebesar 21,35 ${ }^{\circ} \mathrm{C}$ dan temperatur tertinggi sebesar 28,48 ${ }^{\circ} \mathrm{C}$. Kelembaban udara rata-rata harian pada bulan Maret, April, dan Mei masing-masing sebesar 63,36; 62,79; dan 62,66\%.

Kondisi pertanaman karet yang dijadikan sebagai tanaman sampel percobaan secara umum tidak menunjukkan gejala kerusakan atau perubahan akibat perlakuan yang diberikan, sejak awal hingga akhir percobaan. Perubahan kondisi tanaman hanya terjadi pada lima tanaman sampel $(7,57 \%$ dari seluruh tanaman percobaan) memperlihatkan gejala Kering Alur Sadap (KAS), yaitu untuk sampel tanaman pada perlakuan A, F, G, H, dan J. Gejala kering alur sadap ini mulai terlihat setelah aplikasi pertama stimulan cair. Awalnya kelima tanaman tersebut tergolong sebagai tanaman sehat, antara lain berdasarkan penampilan morfologisnya, dan kondisi daun tanaman tidak meranggas. Akibat terjadinya kering alur sadap ini maka pohon karet tersebut tidak dapat menghasilkan lateks.

Gejala kering alur sadap yang terjadi pada kelima tanaman sampel tersebut diduga akibat kondisi fisiologis tanaman yang kurang baik, sehingga memberikan respons negatif terhadap aplikasi stimulan cair. Kondisi fisiologis tersebut diduga dipengaruhi oleh kurangnya pasokan nutrisi melalui kegiatan pemupukan. Menurut Syakir (2010), pemberian stimulan yang intens tanpa diimbangi dengan pemupukan yang cukup dapat menyebabkan terjadinya kering alur sadap. Tanaman yang terkena kering alur sadap biasanya ditangani dengan pemberian senyawa yang mampu mengendalikan kering alur sadap. Selanjutnya tanaman tersebut tidak disadap selama satu bulan atau sampai kulit kembali pulih.

Pengamatan Utama. Variabel yang diamati meliputi volume lateks, berat lump dan kadar karet kering (KKK).
Volume Lateks. Pemberian stimulan pada tanaman karet umumnya dapat memperpanjang masa aliran lateks hingga 24 jam, sedangkan tanaman yang tidak diberi stimulan biasanya hanya sampai 6 jam (Siregar, 2001). Stimulan yang berbahan aktif etefon akan terhidrolisis di dalam jaringan tanaman, menghasilkan gas etilen lalu menstabilkan lutoid dan menunda penyumbatan pembuluh lateks. Gas etilen juga dapat menurunkan aktivitas enzim oksidase oDPO serta meningkatkan tekanan turgor dan kandungan fosfor lateks (Elias, 1982). Hasil uji jarak berganda Duncan rata-rata produksi lateks per pohon disajikan pada Tabel 1 di bawah ini.

Tabel 1. Pengaruh metode aplikasi dan dosis stimulan cair terhadap rata-rata produksi lateks per pohon setiap penyadapan selama periode sadap bulan Maret, April, dan Mei tahun 2015.

\begin{tabular}{cccc}
\hline & \multicolumn{3}{c}{ Volume Lateks } \\
& Maret & April & Mei \\
\cline { 2 - 4 } Perlakuan & $262,72 \mathrm{a}$ & $244,33 \mathrm{a}$ & $257,39 \mathrm{a}$ \\
$\mathrm{nyyy}$ A & $164,89 \mathrm{~b}$ & $138,78 \mathrm{c}$ & $133,67 \mathrm{~b}$ \\
$\mathrm{~B}$ & $245,72 \mathrm{ab}$ & $223,83 \mathrm{ab}$ & $191,72 \mathrm{ab}$ \\
$\mathrm{C}$ & $175,56 \mathrm{~b}$ & $167,78 \mathrm{abc}$ & $175,06 \mathrm{ab}$ \\
$\mathrm{D}$ & $192,72 \mathrm{ab}$ & $160,67 \mathrm{bc}$ & $145,56 \mathrm{ab}$ \\
$\mathrm{E}$ & $165,67 \mathrm{~b}$ & $154,22 \mathrm{bc}$ & $153,06 \mathrm{ab}$ \\
$\mathrm{F}$ & $190,94 \mathrm{ab}$ & $186,89 \mathrm{abc}$ & $180,11 \mathrm{ab}$ \\
$\mathrm{G}$ & $210,11 \mathrm{ab}$ & $192,28 \mathrm{abc}$ & $186,22 \mathrm{ab}$ \\
$\mathrm{H}$ & $193,11 \mathrm{ab}$ & $166,28 \mathrm{abc}$ & $154,33 \mathrm{ab}$ \\
$\mathrm{I}$ & $175,89 \mathrm{~b}$ & $162,17 \mathrm{bc}$ & $163,33 \mathrm{ab}$ \\
$\mathrm{J}$ & $171,33 \mathrm{~b}$ & $155,56 \mathrm{bc}$ & $138,39 \mathrm{~b}$ \\
K & &
\end{tabular}

Keterangan: Nilai rata-rata yang diikuti huruf yang sama menunjukkan tidak berbeda nyata menurut Uji Jarak Berganda Duncan pada taraf kepercayaan 95\%

Berdasarkan Tabel 1 di atas, pada periode sadap bulan Maret dan bulan Mei, penggunaan metode groove dengan dosis $0,5 \mathrm{~mL} /$ pohon (perlakuan B) nyata memberikan hasil yang lebih rendah dibandingkan dengan perlakuan yang tidak diaplikasikan stimulan cair (perlakuan A), tetapi tidak berbeda nyata dengan perlakuan lainnya. Pada periode sadap bulan April, perlakuan B juga nyata memberikan hasil yang lebih rendah dibandingkan dengan perlakuan A dan perlakuan C (metode groove + dosis 0,6 $\mathrm{mL} /$ pohon), tetapi tidak berbeda nyata dengan perlakuan lainnya. Perlakuan B menggunakan metode groove yang merupakan metode yang biasa digunakan di perkebunan, tetapi dosis yang digunakan merupakan dosis yang paling rendah jika dibandingkan dengan dosis yang 
biasa digunakan di perkebunan $(0,8 \mathrm{~mL} /$ pohon), sementara dosis anjuran ethrel berkisar antara 0,6 sampai 0,9 mL/pohon (Hakim, 2012).

Penggunaan dosis stimulan $0,9 \mathrm{~mL} /$ pohon dengan metode groove menghasilkan volume lateks yang nyata lebih rendah dibandingkan dengan perlakuan yang tidak diaplikasikan stimulan (perlakuan A) kecuali pada periode sadap ketiga (bulan Mei), sementara kombinasi dosis $0,9 \mathrm{~mL} /$ pohon dengan metode bark menghasilkan volume lateks yang nyata lebih rendah dibandingkan dengan perlakuan A dari periode sadap pertama sampai periode sadap ketiga. Penggunaan dosis stimulan 0,5 $\mathrm{mL} /$ pohon dengan metode groove menghasilkan volume lateks yang nyata lebih rendah dibandingkan dengan perlakuan A dari periode sadap pertama sampai periode sadap ketiga, sementara kombinasi dosis $0,5 \mathrm{~mL}$ dengan metode bark menghasilkan volume lateks yang tidak berbeda nyata dibandingkan dengan perlakuan A dari periode sadap pertama sampai periode sadap ketiga.

Hal tersebut di atas menunjukkan bahwa kombinasi antara metode aplikasi dan dosis stimulan cair memberikan respons hasil volume lateks per pohon yang berbeda. Respons tersebut timbul dalam waktu yang beragam antara periode sadap pertama, kedua, dan ketiga, yang diperlihatkan dengan adanya perubahan volume lateks yang dihasilkan dari masing-masing perlakuan pada setiap periode sadap.

Perbedaan respons tanaman terhadap perlakuan yang diaplikasikan diduga disebabkan oleh beberapa faktor. Menurut Setiawan dan Andoko (2005), beberapa faktor yang mempengaruhi respons tanaman terhadap aplikasi stimulan diantaranya jenis klon yang digunakan, umur tanaman, teknik aplikasi stimulan, dosis, dan faktor lingkungan tumbuh tanaman. Faktor lain yang dapat mempengaruhi respons tanaman terhadap aplikasi stimulan di lahan percobaan diduga karena kurangnya nutrisi tanaman yang diberikan melalui proses pemupukan. Hal ini disebabkan karena Standar Operasional Prosedur (SOP) pihak perkebunan PT. PP Bajabang Indonesia tidak melakukan kegiatan pemupukan terhadap tanaman karet yang sudah berumur di atas 23 tahun. Menurut Syakir (2010), kebutuhan tanaman karet akan unsur hara perlu dipenuhi, karena dengan tercukupinya unsur hara metabolisme tanaman mampu bekerja secara optimal untuk menghasilkan lateks.
Rata-rata produksi lateks pada perlakuan yang tidak diaplikasikan stimulan cair (perlakuan A) menunjukkan hasil yang lebih tinggi dibandingkan dengan perlakuan lainnya, dikarenakan tidak adanya gangguan terhadap proses fisiologis yang terjadi dalam tubuh tanaman akibat pemberian stimulan. Jika stimulan diberikan pada tanaman dengan kondisi yang kurang baik maka diduga dapat mempengaruhi keseimbangan fisiologis tanaman sehingga memberikan pengaruh negatif, salah satunya adalah penurunan produksi lateks. Produksi lateks yang tidak berbeda nyata dengan perlakuan A diduga tidak menyebabkan dampak negatif yang dapat menurunkan produksi lateks, sedangkan aplikasi stimulan pada tanaman yang menghasilkan produksi lateks nyata lebih rendah dibandingkan perlakuan A menunjukkan adanya pengaruh yang negatif terhadap produksi lateks.

Faktor lain yang mempengaruhi respons tanaman terhadap aplikasi stimulan adalah bidang sadap yang digunakan, dimana pada penelitian ini bidang sadap yang digunakan merupakan kulit pulihan 3. Kulit pulihan 3 tidak sebaik kulit pulihan 1 dan 2 dalam menghasilkan lateks karena kondisi kulit tersebut sudah kurang baik (Haryo, 2015).

Ketebalan kulit pada kulit pulihan 3 lebih tipis dibandingkan dengan kulit pada pulihan 1 dan 2. Hal ini diduga disebabkan karena kecepatan regenerasi kulit pada tanaman tua lebih lambat dibandingkan dengan tanaman muda. Kulit pulihan 3 sudah menipis mendekati kambium dan pada tanaman tua terjadi pertumbuhan sekunder yaitu pembentukan suberin. Suberin merupakan zat lilin yang melindungi sel gabus yang terbentuk pada kulit pohon (Salisbury dan Ross, 1995). Pembentukan suberin ini dipacu pula oleh adanya pelukaan melalui kegiatan penyadapan. Kondisi tersebut diduga dapat menyebabkan terhambatnya proses pengeluaran lateks.

Lump. Hasil uji lanjut pada metode aplikasi dan dosis stimulan cair tidak menunjukkan pengaruh yang berbeda nyata terhadap rata-rata produksi lump per pohon. Data ratarata produksi lump per pohon setiap penyadapan pada periode sadap Bulan Maret, April, dan Mei Tahun 2015 disajikan pada Tabel 2.

Tanaman karet dinilai baik apabila mampu menghasilkan lateks yang tinggi dengan jumlah lump yang kecil (Setyamidjaja, 1993). Banyaknya lump yang dihasilkan disebabkan karena 
karakter spesifik yang dimiliki klon PR 300 yaitu memiliki sifat lambat dalam proses penetesan lateks. Hal ini juga disebabkan karena penampungan lateks hanya dilakukan selama 4 jam setelah penyadapan, sementara lateks tersebut masih terus menetes pada mangkuk sadap dan hasil tampungannya membentuk gumpalan yang disebut lump. Penampungan lateks idealnya dilakukan selama kurang lebih 6 jam dengan syarat kondisi lateks tidak sampai menggumpal.

Tabel 2. Pengaruh metode aplikasi dan dosis stimulan cair terhadap rata-rata produksi lump per pohon setiap penyadapan selama periode sadap bulan Maret, April, dan Mei tahun 2015.

\begin{tabular}{cccc}
\hline \multirow{2}{*}{ Perlakuan } & \multicolumn{3}{c}{ Berat Lump (g/pohon/penyadapan) } \\
\cline { 2 - 4 } & Maret & April & Mei \\
\hline A & $50,58 \mathrm{a}$ & $63,67 \mathrm{a}$ & $27,79 \mathrm{a}$ \\
B & $41,89 \mathrm{a}$ & $28,78 \mathrm{a}$ & $10,34 \mathrm{a}$ \\
C & $86,62 \mathrm{a}$ & $73,36 \mathrm{a}$ & $21,04 \mathrm{a}$ \\
D & $60,66 \mathrm{a}$ & $58,95 \mathrm{a}$ & $17,49 \mathrm{a}$ \\
E & $49,97 \mathrm{a}$ & $45,77 \mathrm{a}$ & $19,15 \mathrm{a}$ \\
F & $48,82 \mathrm{a}$ & $45,36 \mathrm{a}$ & $19,21 \mathrm{a}$ \\
G & $43,32 \mathrm{a}$ & $52,72 \mathrm{a}$ & $25,50 \mathrm{a}$ \\
H & $77,35 \mathrm{a}$ & $75,47 \mathrm{a}$ & $56,13 \mathrm{a}$ \\
I & $30,05 \mathrm{a}$ & $47,07 \mathrm{a}$ & $24,06 \mathrm{a}$ \\
J & $44,98 \mathrm{a}$ & $36,86 \mathrm{a}$ & $16,53 \mathrm{a}$ \\
K & $41,29 \mathrm{a}$ & $42,99 \mathrm{a}$ & $36,97 \mathrm{a}$ \\
\hline
\end{tabular}

Keterangan: Nilai rata-rata yang diikuti huruf yang sama menunjukkan tidak berbeda nyata menurut Uji Jarak Berganda Duncan pada taraf kepercayaan $95 \%$

Tabel 3. Pengaruh metode aplikasi dan dosis stimulan cair terhadap rata-rata nilai kadar karet kering per pohon selama periode sadap bulan Maret, April, dan Mei tahun 2015

\begin{tabular}{cccc}
\hline & \multicolumn{3}{c}{ Kadar Karet Kering (\%/pohon) } \\
\cline { 2 - 4 } Perlakuan & Maret & April & Mei \\
\hline A & 31 & 31 & 30 \\
B & 31 & 29 & 27 \\
C & 30 & 29 & 32 \\
D & 29 & 30 & 31 \\
E & 31 & 31 & 28 \\
F & 28 & 28 & 26 \\
G & 29 & 27 & 31 \\
H & 32 & 29 & 30 \\
I & 26 & 30 & 31 \\
J & 31 & 26 & 29 \\
K & 28 & 28 & 28 \\
\hline
\end{tabular}

Penggunaan stimulan pada dasarnya bertujuan untuk memperpanjang masa aliran lateks dengan cara menunda koagulasi dan penyumbatan pembuluh lateks (Siregar, 2001). Penggunaan stimulan pada percobaan ini diduga tidak bekerja secara optimal sesuai dengan fungsinya. Hal ini terbukti dengan dihasilkannya bobot lump yang tidak berbeda nyata untuk setiap perlakuan.

Kadar Karet Kering (KKK). Pengukuran kadar karet kering (KKK) dilakukan dengan tujuan untuk mengetahui besarnya kadar karet kering lateks yang dihasilkan dan menjadi acuan untuk menentukan besarnya kebutuhan asam semut yang digunakan untuk menggumpalkan lateks. Data rata-rata nilai KKK per pohon pada periode sadap bulan Maret, April, dan Mei Tahun 2015 disajikan pada Tabel 3.

Kualitas lateks dinilai baik apabila nilai kadar karet keringnya di atas $25 \%$ karena pada kondisi tersebut kadar airnya tidak terlalu besar sehingga karet yang dihasilkan akan lebih baik dibandingkan dengan lateks yang memiliki kadar karet kering di bawah 25\% (Setyamidjaja, 1993). Penggunaan stimulan pada umumnya dapat meningkatkan volume lateks yang dihasilkan, akan tetapi diikuti dengan nilai kadar karet kering yang rendah (Siregar, 2001). Hasil pengukuran kadar karet kering tiap perlakuan menunjukan nilai rata-rata sebesar 30 $\%$, yang artinya sudah di atas standar nilai kadar karet kering (Syakir, 2010). Hal ini disebabkan karena lateks pada tanaman tua lebih kental dibandingkan dengan tanaman muda. Lilit batang pada tanaman tua lebih besar dan kandungan klorofil yang dimiliki daun lebih tinggi sehingga menghasilkan lateks yang lebih kental (Haryo, 2015).

Nilai kadar karet kering dipengaruhi pula oleh karakter genetis yang dimiliki oleh setiap klon. Klon PR 300 merupakan klon yang memiliki sifat lambat dalam penetesan lateksnya, hal ini menunjukkan bahwa klon PR 300 memiliki tingkat kekentalan lateks yang relatif tinggi yang tergambar dari nilai kadar karet kering yang tinggi pula. Berbeda halnya dengan klon yang tergolong klon quick starter yang memiliki kekentalan lateks yang lebih rendah dibandingkan dengan klon PR 300, yaitu berkisar antara 25-28 \% (PTPN VIII Batulawang, 2014).

\section{Kesimpulan dan Saran}

Berdasarkan hasil percobaan dan pembahasan, dapat ditarik beberapa kesimpulan, diantaranya: 
a. Kombinasi metode aplikasi dan dosis stimulan cair berpengaruh terhadap volume lateks, tetapi tidak berpengaruh terhadap berat lump dan kadar karet kering pada tanaman karet klon PR 300 usia 25 tahun.

b. Metode aplikasi groove dan bark yang dikombinasikan dengan beberapa dosis stimulan cair menghasilkan volume lateks yang relatif sama pada klon PR 300 usia 25 tahun.

c. Berdasarkan hasil peneitian, sebaiknya pemberian stimulan diikuti dengan pemeliharaan yang baik

d. Tidak dianjurkan aplikasi stimulan dilakukan pada tanaman berumur 25 tahun.

\section{Daftar Pustaka}

Balai Pengkajian Teknologi Pertanian. 2011. Sukses membangun kebun bibit karet unggul. Tersedia online: http://sumbar. litbang.pertanian.go.id/ind/index.php? option $=$ com_content\&view $=$ article\&id $=529$ :sukses-membangun-kebun-bibit-karetunggul-\&catid=1:info-teknologi (Diakses pada 27 November 2014)

Direktorat Jenderal Perkebunan. 2017. Statistik Perkebunan Indonesia. Dirjenbun. Jakarta.

Direktorat Jenderal Perkebunan. 2011. Komoditi karet sebagai sumber devisa negara, peluang usaha perkebunan karet. Tersedia online: http://www.bumn.go.id/ptpn5/ berita/9371/Komoditi.Karet.sebagai.sumbe r.devisa.negara,.Peluang.Usaha.Perkebuna n.Karet (Diakses pada 27 November 2014).

Elias, B.A. 1982. The physiology and biochemis- try of latex flow, RRIM. RRIM Training on Tapping, Tapping systems and yield stimulation of Hevea.p. 15-23.

Hakim, Syaiful. 2012.Ethrel 10pa tingkatkan produksi karet. Tersedia online: http://www.agrina-online.com/redesign2. php?rid=7\&aid $=4028$ (Diakses pada 24 November 2014).

Haryo. 2015. Komunikasi Pribadi PT. PP Bajabang Indonesia.

Hidayat, M. S. 2014. Produktivitas karet nasional kalah dari Malaysia dan Thailand. Jakarta. Tersedia online: http://www.kemenperin. go.id/ artikel/7341/Produktivitas-KaretNasional-Kalah-dari-Malaysia-dan-

Thailand(diakses pada 24 November 2014).

PTPN VIII Batulawang. 2014. Data Produksi Lateks Periode Sadap Tahun 2013-2014.

Salisbury FB, dan CW Ross. 1995. Fisiologi Tumbuhan, Jilid 2. Penerjemah: Lukman DR, Sumaryono. Bandung:Penerbit ITB. Hal:139-140.

Setiawan, D. H dan A. Andoko, 2005. Petunjuk Lengkap Budi Daya Karet. Agromedia Pustaka, Jakarta. Hlm 121-138.

Setyamidjaja, D., 1993. Karet Budidaya dan Pengolahan. Penerbit Kanisius. Yogyakarta. Hlm 117-151.

Siregar, Tumpal HS. 2001. Teknik Penyadapan Karet. Kanisius. Yogyakarta. Hal 37-39.

Syakir, M. 2010. Budidaya dan pasca panen karet. Pusat Penelitian dan Pengembangan Perkebunan. Tersedia online: http:// perkebunan. litbang. deptan.go.id/wp-content/ uploads/2012/08/perkebunan_budidaya_ karet.pdf (Diakses pada 24 Nov. 2014). 